\title{
The Role of Export Entrepreneurship Effective Factors in Export Performance
}

\author{
Elham Asghari \\ Department of Management, \\ Faculty of Humanities \\ South Tehran Branch, Islamic Azad University \\ Tehran, Iran
}

\author{
Ali Reza Rezghi Rostami \\ Department of Management, \\ Faculty of Humanities \\ South Tehran Branch, Islamic Azad University \\ Tehran, Iran
}

\begin{abstract}
This research aims to investigate the role of export entrepreneurship effective factors in export performance. Research statistical population contains sales managers and top managers working in manufacturing companies of precious and decorative stones in Firuzeh, a city in Iran. In order to gather data, a questionnaire consisting of 32 questions has been used. The validity of the questionnaire was confirmed by supervisors and advisors and its reliability has been assessed $(0.865)$ using Cronbach's alpha coefficient. Five hypotheses have been proposed for this research. Two methods of descriptive and inferential statistics have been used to analyze the data in this study. In the descriptive part, frequency number, frequency percentage, and frequency graph have been employed. Statistical analysis on data collected show that the variables of management commitment, resources, and the intensity of competition have significant positive impact on export entrepreneurship while the variable market distance does not have significant positive impact on export entrepreneurship. In addition, export entrepreneurship has a significant positive impact on export performance.
\end{abstract}

Keywords-management commitment; resources and the intensity of competition; exports entrepreneurship; market distance

\section{INTRODUCTION}

Every country needs an export strategy to survive in the global markets and gain a larger share, or at least maintain its current position. In this regard, every country requires a identification of its market structure and its developments [1]. Designing strategies for entering international markets is complex and difficult because of the dynamic nature and complexity of the issue as well as the impact of different variables. Therefore, it is necessary to identify important variables determining strategies for entering international markets and export [2]. Studies show that Iran holds little contribution from international markets in spite of having a high potential for export. A major part of the country's foreign exchange earnings is obtained from oil exports. This dependence is not desirable for several reasons.

- Oil price, and its export, is subject to severe fluctuations; the fluctuations have undesirable consequences on economic activities,
- Oil export is subject to international restrictions; an increase in its export does not necessarily lead to an increase in foreign exchange revenues,

- Oil is an exhaustible material; its export is like the export of capital and its export should not be regarded as the export of other goods.

Accordingly, export development is one of the main objectives of non-oil economy. The presence of knowledge, information, experience, and resources is essential for overcoming this problem for firms. Moreover, export promotion programs should be defined meet this need and help the learning process in international competitive environment as well as motivating business environment toward export goals and providing the necessary infrastructure to facilitate export. Besides, composition of exported goods requires reform and improvement. All these factors indicate lack of attention to export entrepreneurship in the country. With these lines, this research seeks to find the role of export entrepreneurship effective factors in export performance. Spatial domain of the research is manufacturing companies of precious and decorative stones in Firuzeh and the time domain in the year 2015.

\section{THEORETICAL FOUNDATIONS}

Considering the research subject under study, theoretical literature of each key word in this study is as follows:

- Export: Export is the easiest way to enter the foreign market. Case export occurs when companies sell goods passively to buyers in foreign countries time to time due to having products in excess of domestic consumption. Active export occurs when a company decides to export its products to the target country. In both cases, the company may produce the product in its own country and transform them for the target company, or export them in the same shape having been consumed in the domestic lands [3].

- Export marketing: It is an integrated marketing of goods and services supplied to customers in international markets. In general, export marketing contains all marketing activities carried out by a company to supply products outside the domestic markets [4]. 
- Export entrepreneurship: Ibeh and Young [5] have defined export entrepreneurship (EE) as a process in which individuals will benefit from market opportunities in foreign markets by themselves or within the organization by considering available resources and environmental factors that effect on them. The definition highlights dependence of export entrepreneurship to internal resources as well as external and environmental factors.

- Export performance: Classification of the determinants of export performance to internal and external factors is theoretically reasonable because internal determinants are founded based on resource-based theory and determining external factors are established based on industry structure theory. Resource-based theory regards a company as a special package of touchable and untouchable resources (assets, competencies, processes, management characteristics, information, and knowledge). They are controllable by the company and enable the company to adjust strategies to improve its efficiency and effectiveness [6]. The theory argues that the resources within an organization are the determinants of export performance and corporate strategy.

\section{LITERATURE REVIEW}

Given the novelty of the subject, a study that examines all variables has not been found. However, there are some relevant studies inside and outside Iran in this regard. In [7], authors studied the influence of uncertainty on marketing mix strategy elements in emerging business-to-business export-markets. They tried to find whether the degree and rate of compatibility and standardization depends on the management understanding of uncertainty and whether export entrepreneurship ability of a company (employment of networks, influences positively on the positive evaluation of environment. Data collected from German companies that worked in international trading markets. The results show that the use of international entrepreneurship is more effective than using networks in reducing uncertainty. In [8], it was pointed out that export had a direct role in the development and economic growth; hence, using a variety of programs to encourage export, dozens of Iranian government agencies and private companies take action to support their export activities. These programs aim to improve the export performance of companies or stimulating them to continue and initiate export activities. In order to evaluate the impact of these supportive programs on export performance of companies, a descriptive survey research has been carried out on exporting companies in the industrial area of Khorasan Razavi. The research sought to determine strategies to increase export performance for companies that intend to export goods or companies that recently have been on this path. The investigation presented a conceptual model through theoretical foundations in this regard. It analyzed the conceptual model constituted of one main hypothesis and five secondary hypotheses [8]. In [4], authors implied that uncertainty of host country, uncertainty of product market, competitive uncertainty, uncertainty of partner behavior, international experience, technical knowledge, marketing skills, total investment, competitive intensity, nature of foreign activity, attractiveness of location and business relatedness affect selecting foreign market entry strategies. Moreover, attractiveness of location, language diversity and uncertainty of the host country are proved to be good manifests of the companies' strategic focus. Uncertainty of host country, uncertainty of product market, competitive uncertainty, international experience, firm size, technical knowledge, marketing skill, total investment, business relatedness, and the nature of foreign activity are good manifests for the degree of control over their foreign activities [4].

\section{RESEARCH HYPOTHESES AND RESEARCH MODEL}

The model is presented in Figure 1. The model presents the relationships between research variables including management commitment, resources, competition intensity, market distance, export entrepreneurship, and finally export performance. This model provides principal and significant structures that have been proposed in the literature in a comprehensive way. Accordingly, research hypotheses are as follows:

- Management commitment to export has a positive impact on export entrepreneurship.

- Company resources have a positive impact on export entrepreneurship.

- Intensity of competition has a positive impact on export entrepreneurship.

- Market distance has a negative impact on export entrepreneurship.

- Export entrepreneurship has a positive impact on export performance.

\section{StATISTICAL POPULATION AND STATISTICAL SAMPLE}

Research statistical population contains sales managers and top managers working in manufacturing companies of precious and decorative stones in Firuzeh, a city in Iran. Random sampling is applied. All members of the community have equal chances to be selected. In other words, ii the number of community members is regarded $\mathrm{N}$ and the sample size is regarded $\mathrm{n}$, the probability of selecting each member of society is equal to $\mathrm{n} / \mathrm{N}$. Random sampling can be performed in two ways. First, draw; second, using a table of random numbers. This study has used the first method (draw). The research employs one of the most important and the most recent sample selection rules. The rule suggests for path model estimates of partial least squares method that the model size should be equal to or greater than the following items:

- Ten times the number of indicators of the scale with the largest number of formative indicators, or

- Ten times the largest number of structural paths directed at a particular construct in the inner path model [9].

Considering research conceptual model and observing the above rules, the minimum required sample size for this study is 40. Since some of the collected questionnaires may have inconsistent and unreliable data and many respondents refuse to fill the questionnaires, 70 questionnaires have been distributed. 


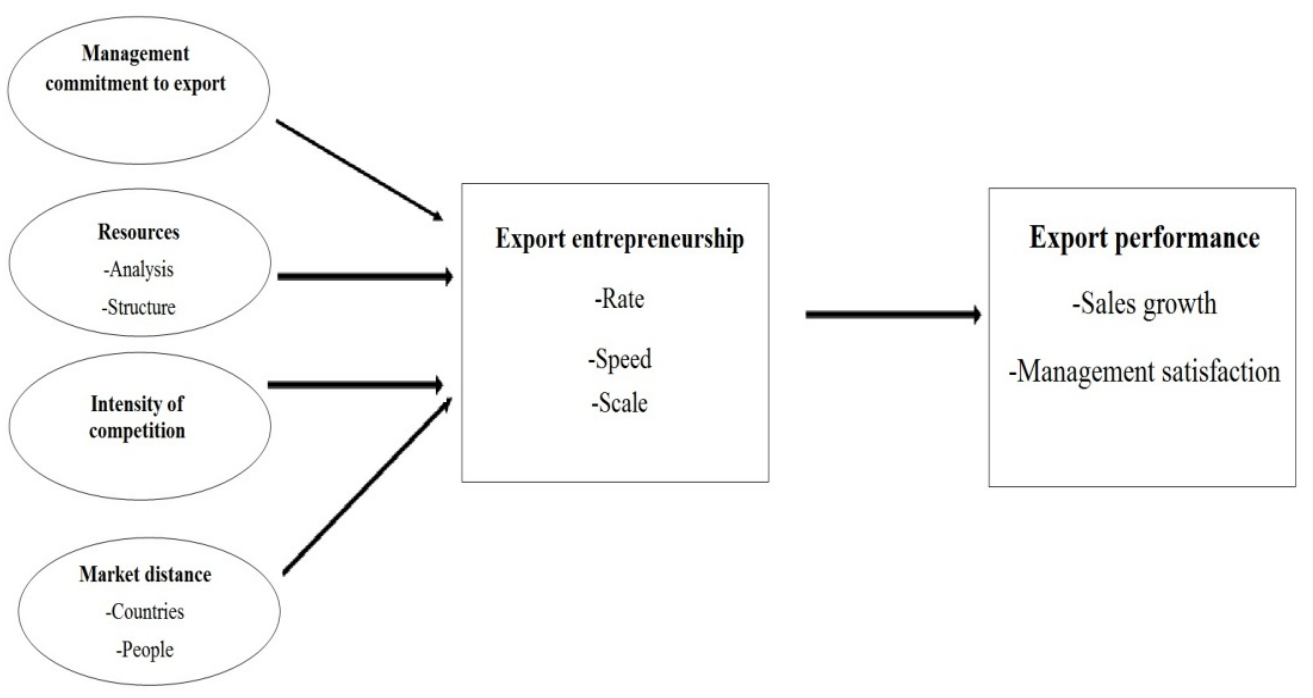

Fig. 1. Research conceptual model

\section{RESEARCH METHODOLOGY}

This study can be considered an applied research according to its objectives because an applied research aims to develop practical knowledge in a particular field. Moreover, it can be regarded as a descriptive-analytical research since it explains and develops the ways and reasons of the problem and its dimensions in addition to illustration of the facts. Researchers need a strong argument to support for explaining and justifying reasons. The argument is acquired by searching the literature, theoretical discussions, formulation of general statements, and available propositions. The researcher connects logically his concerns with relevant general statements; then he makes a conclusion. It is noteworthy to state that each research is valuable in its own place. Library based methods (books, articles and dissertations in English and Farsi) have been used to collect information on the theoretical background of research; moreover, questionnaire has been used to gather data in the main part of the research. In the first phase, books, articles, theses, online surveys have been useful. Parametric and nonparametric statistical methods have been used to analyze data in this research. Variance-based structural equation with partial least squares method has been employed to describe data and explain demographic characteristics of descriptive statistics, data analysis, and testing hypotheses and conceptual model.

\section{FINDINGS}

\section{A. Describing Research Variables}

With regard to conceptual model, research variables are market distance, intensity of competition, resources, management commitment, export entrepreneurship, and export performance. In order to address research variables in the software, the coding presented in Table I has been used.
TABLE I. CODING OF DIMENSIONS AND ITS RELATED VARIABLES

\begin{tabular}{|l|c|}
\hline \multicolumn{1}{|c|}{ Variable } & Variable Code \\
\hline Market Distance & MAR \\
\hline Intensity of competition & COM \\
\hline Resources & RES \\
\hline Management commitment & MAN \\
\hline Export entrepreneurship & ENT \\
\hline Export performance & PER \\
\hline
\end{tabular}

\section{B. Reliability and validity of research data}

In the researches using partial least squares method, reliability should be calculated for both constructs and indicators. Reliability of structures has been examined by Cronbach's alpha and Dillon-Goldstein's rho. The minimum acceptable value for the coefficients is 0.7 . As specified in Table II, the values of Cronbach's alpha and Dillon-Goldstein's rho are higher than 0.7 ; it indicates very high reliability of constructs.

TABLE II. THE RELIABILITY OF CONSTRUCTS

\begin{tabular}{|l|c|c|}
\hline \multicolumn{1}{|c|}{ Construct } & Cronbach's alpha & Dillon-Goldstein's rho \\
\hline Intensity of competition & 0.8984 & 0.9254 \\
\hline Export entrepreneurship & 0.8134 & 0.8891 \\
\hline Management commitment & 0.8237 & 0.8824 \\
\hline Market Distance & 0.9132 & 0.9248 \\
\hline Export performance & 0.9341 & 0.9501 \\
\hline Resources & 0.8993 & 0.9261 \\
\hline
\end{tabular}

Load factors have been tested to assess the reliability of indicators. In this examination, load factor of indicators should be higher than 0.7. Coefficients of factor loadings for questions in the questionnaire are shown in Tables III-VIII. 
TABLE III. LOAD FACTOR COEFFICIENTS FOR THE CONSTRUCT OF MARKET DISTANCE

\begin{tabular}{|l|c|c|c|c|c|}
\hline Questions & MARK 1 & MARK 2 & MARK 3 & MARK 4 & MARK 5 \\
\hline Load factor & 0.730 & 0.740 & 0.723 & 0.678 & 0.781 \\
\hline Questions & MARK 6 & MARK 7 & MARK 8 & MARK 9 & MARK 10 \\
\hline Load factor & 0.789 & 0.71 & 0.759 & 0.784 & 0.725 \\
\hline
\end{tabular}

TABLE IV. LOAD FACTOR COEFFICIENTS FOR THE CONSTRUCT OF COMPETITION INTENSITY

\begin{tabular}{|l|c|c|c|c|c|}
\hline Questions & COM 1 & COM 2 & COM 3 & COM 4 & COM 5 \\
\hline Load factor & 0.809 & 0.794 & 0.906 & 0.877 & 0.885 \\
\hline
\end{tabular}

TABLE V. LOAD FACTOR COEFFICIENTS FOR THE CONSTRUCT OF EXPORT ENTREPRENEURSHIP

\begin{tabular}{|l|c|c|c|}
\hline Questions & ENT 1 & ENT 2 & ENT 3 \\
\hline Load factor & 0.902 & 0.828 & 0.828 \\
\hline
\end{tabular}

TABLE VI. LOAD FACTOR COEFFICIENTS FOR THE CONSTRUCT OF MANAGEMENT COMMITMENT

\begin{tabular}{|l|c|c|c|c|}
\hline Questions & MAN 1 & MAN 2 & MAN 3 & MAN 4 \\
\hline Load factor & 0.850 & 0.794 & 0.768 & 0.817 \\
\hline
\end{tabular}

TABLE VII. LOAD FACTOR COEFFICIENTS FOR THE CONSTRUCT OF EXPORT PERFORMANCE

\begin{tabular}{|l|c|c|c|c|c|}
\hline Questions & PER 1 & PER 2 & PER 3 & PER 4 & PER 5 \\
\hline Load factor & 0.939 & 0.898 & 0.891 & 0.911 & 0.814 \\
\hline
\end{tabular}

TABLE VIII. LOAD FACTOR COEFFICIENTS FOR THE CONSTRUCT OF RESOURCES

\begin{tabular}{|l|c|c|c|c|c|}
\hline Questions & RES 1 & RES 2 & RES 3 & RES 4 & RES 5 \\
\hline Load factor & 0.680 & 0.890 & 0.875 & 0.891 & 0.878 \\
\hline
\end{tabular}

As seen in the above Tables, most indicators have a load factor higher than 0.7 . Only indicators of RES 1 and MARK 4 have load factors less than 0.7. According to rule 1 and the average variance extracted of higher 0.5 for the related constructs, the indicators can be maintained. Both convergent validity and discriminant validity must be calculated to assess assess the validity in the partial least squares model. The average variance extracted (AVE) has been used to calculate the convergent validity; the results are represented in Table IX. The value for average variance extracted for all variables is higher than 0.5522 ; it implies good convergent validity of the constructs. Chen test has been used to evaluate discriminant validity of the constructs. Square root of the average variance extracted for each construct must be higher than its correlation coefficient of the construct with other constructs. Table $\mathrm{X}$ shows the results in this regard. As can be seen in the table, value of square root of the average variance extracted for all constructs is higher than its correlation coefficient with other constructs. It indicates good discriminant validity of the constructs. Transverse loads have been tested to evaluate discriminant validity of the indicators transverse load for each construct must be higher than its transverse load for other constructs. The results of this test have been displayed in Table XI. The results indicate good discriminant validity of the indicators because all indicators have higher load factors for their construct comparing to their load factors for other constructs.
TABLE IX. VALIDITY OF CONSTRUCTS

\begin{tabular}{|l|c|}
\hline Construct & Average variance extracted \\
\hline Intensity of competition & 0.7140 \\
\hline Export entrepreneurship & 0.7280 \\
\hline Management commitment & 0.6526 \\
\hline Market Distance & 0.5522 \\
\hline Export performance & 0.7925 \\
\hline Resources & 0.7167 \\
\hline
\end{tabular}

TABLE X. CORRELATION MATRIX AND THE SQUARE ROOT OF THE AVERAGE VARIANCE EXTRACTED (CHEN TEST)

\begin{tabular}{|l|c|c|c|c|c|c|}
\hline & COM & ENT & MAN & MAR & PER & RES \\
\hline Construct & 0.8450 & & & & & \\
\hline $\begin{array}{l}\text { Intensity of } \\
\text { competition }\end{array}$ & 0.5948 & 0.8532 & & & & \\
\hline $\begin{array}{l}\text { Export } \\
\text { entrepreneurship }\end{array}$ & 0.3800 & 0.5848 & 0.8078 & & & \\
\hline $\begin{array}{l}\text { Management } \\
\text { commitment }\end{array}$ & 0.1213 & 0.1235 & 0.1454 & 0.7431 & & \\
\hline Market Distance & 0.4790 & 0.3720 & 0.4061 & - & 0.8902 & \\
\hline $\begin{array}{l}\text { Export } \\
\text { performance }\end{array}$ & 0.3877 & 0.6051 & 0.5062 & 0.0299 & 0.2951 & 0.8466 \\
\hline
\end{tabular}

\section{Results of Path Coefficient and Determination Coefficient}

In this section, hypotheses are investigated using PLS algorithms and Bootstrap with 500 su-samples. Results of testing hypotheses are shown in Figures 2 and 3. As observed in Figures, the variables of management commitment, resources, and the intensity of competition have significant positive impacts on export entrepreneurship while the variable market distance does not have significant positive impact on export entrepreneurship. In addition, export entrepreneurship has a significant positive impact on export performance. The impact of variables in addition to path coefficient values, and $\mathrm{T}$-statistics are seen in Table XII.

In general, Table XII shows the relationships among research variables based on research hypotheses, conceptual model, and the software model. The important point in relation to the following table is confirmation of the relations with a $\mathrm{P}$ value less than 0.05 . The relationships with a $\mathrm{P}$ value higher than 0.05 will not be confirmed.

\section{CONCLUSION}

This sections reviews research hypotheses and their confirmation or rejection results. Moreover, each hypothesis will be discussed separately. The first research hypothesis evaluates the impact of management commitment to export on export entrepreneurship. As the results of extracting software indicate, the variable of management commitment to export has a significant positive impact on export entrepreneurship with a path coefficient of 0.281 and t-statistic of 3.502. Therefore, one can assert in interpreting the test results that management commitment to export increases export entrepreneurship significantly. Management commitment to export activities has a strong impact on manufacturers exporting success. To ensure development and maintain regular operations of export, understanding the attitude of foreign buyers and conducting advanced marketing activities are essential. Management commitment to export is very important in order to build such capacity. 


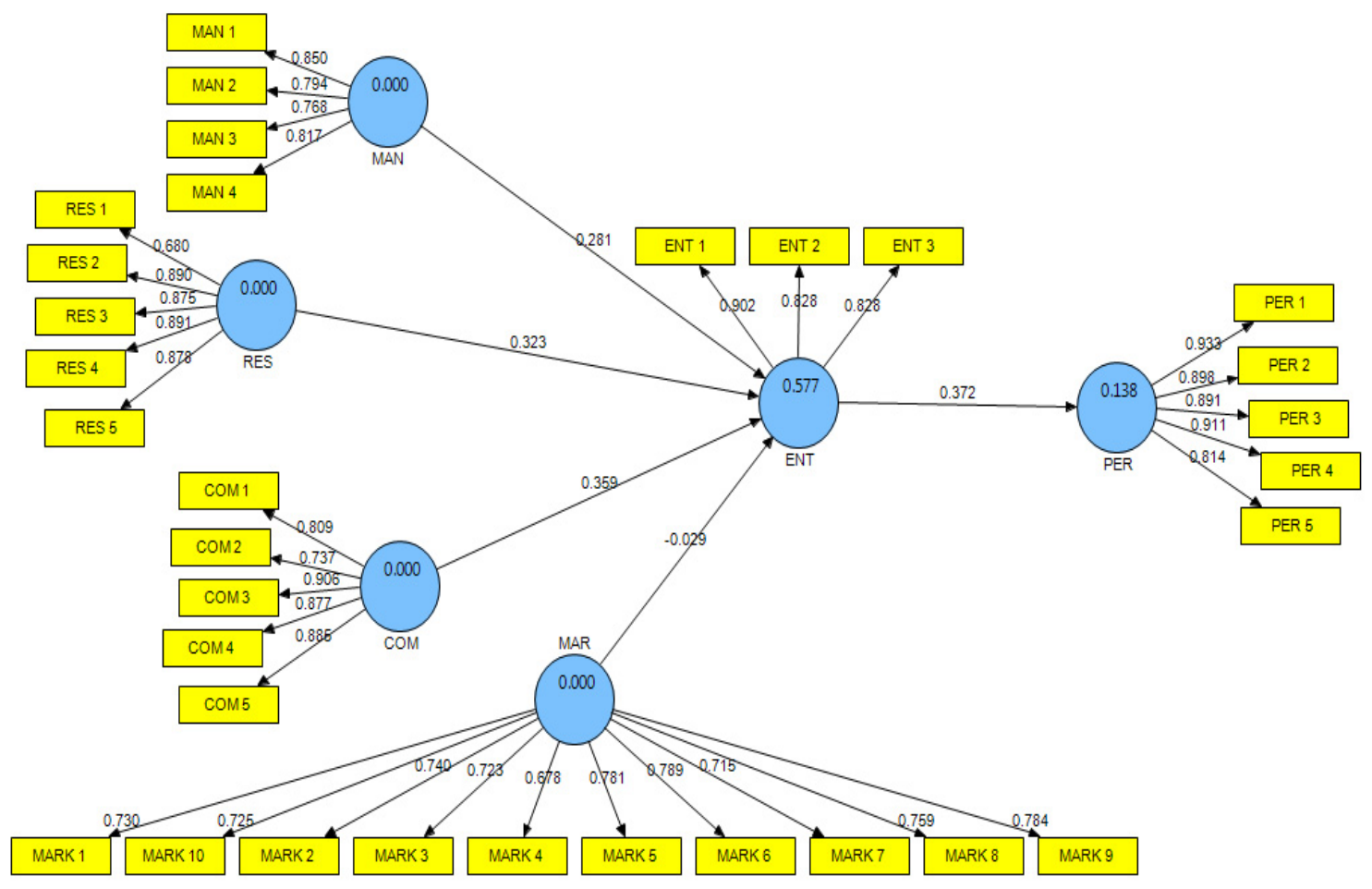

Fig. 2. The path coefficient of the model

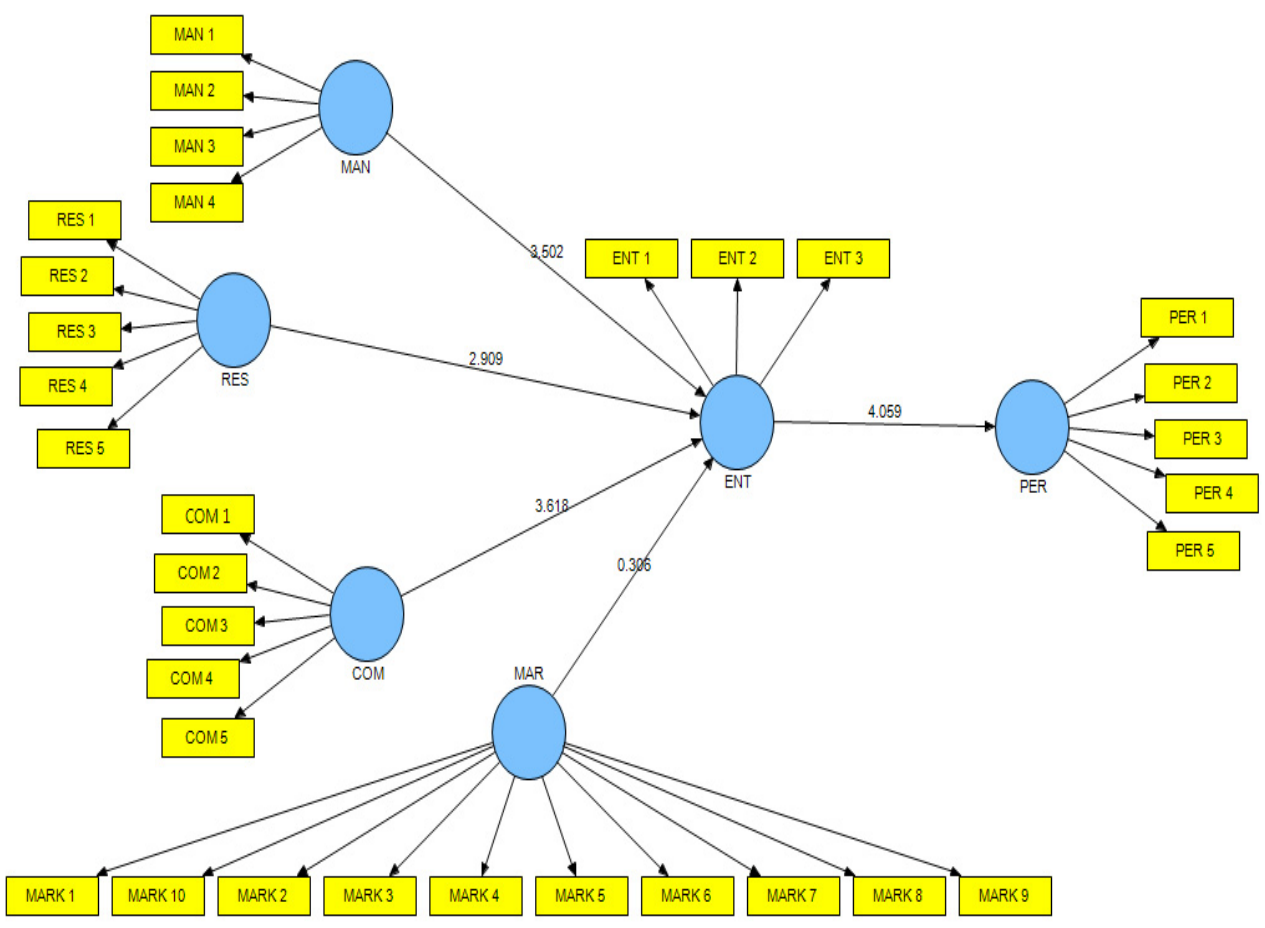

Fig. 3. T-statistic for the model 
TABLE XI. TRANSVERSE LOADS

\begin{tabular}{|c|c|c|c|c|c|c|}
\hline & COM & ENT & MAN & MAR & PER & RES \\
\hline COM 1 & 0.808864 & 0.452173 & 0.210616 & -0.100171 & 0.361601 & 0.370538 \\
\hline COM 2 & 0.737016 & 0.434538 & 0.283773 & -0.035270 & 0.212294 & 0.210336 \\
\hline COM 3 & 0.905673 & 0.519030 & 0.355679 & -0.061211 & 0.472738 & 0.350460 \\
\hline COM 4 & 0.877118 & 0.538961 & 0.358066 & -0.059501 & 0.438944 & 0.349515 \\
\hline COM 5 & 0.884975 & 0.554706 & 0.377591 & -0.239300 & 0.500636 & 0.347376 \\
\hline ENT 1 & 0.574899 & 0.901601 & 0.526353 & -0.150027 & 0.408352 & 0.587529 \\
\hline ENT 2 & 0.540511 & 0.827784 & 0.455370 & -0.168686 & 0.310033 & 0.375263 \\
\hline ENT 3 & 0.394513 & 0.828349 & 0.515148 & 0.014521 & 0.213427 & 0.576516 \\
\hline MAN 1 & 0.330068 & 0.554419 & 0.850458 & -0.114069 & 0.294381 & 0.509294 \\
\hline MAN 2 & 0.186275 & 0.446526 & 0.793509 & -0.075471 & 0.262652 & 0.353580 \\
\hline MAN 3 & 0.302122 & 0.364082 & 0.768097 & -0.174020 & 0.470456 & 0.317498 \\
\hline MAN 4 & 0.399782 & 0.492648 & 0.817114 & -0.119855 & 0.326220 & 0.421318 \\
\hline MARK 1 & -0.007590 & -0.043716 & -0.036422 & 0.729878 & 0.032345 & 0.057823 \\
\hline MARK 2 & -0.061347 & -0.083600 & -0.070596 & 0.739627 & -0.111845 & 0.141535 \\
\hline MARK 3 & 0.037430 & -0.030700 & 0.010919 & 0.722593 & 0.131071 & -0.092055 \\
\hline MARK 4 & -0.120493 & -0.032337 & -0.020617 & 0.678037 & -0.029481 & 0.035685 \\
\hline MARK 5 & -0.069033 & -0.078857 & -0.079448 & 0.781277 & -0.024058 & 0.012909 \\
\hline MARK 6 & -0.162362 & -0.084601 & -0.199506 & 0.789494 & -0.066182 & -0.041273 \\
\hline MARK 7 & -0.096739 & -0.100431 & -0.009396 & 0.714545 & 0.113268 & -0.082526 \\
\hline MARK 8 & -0.042854 & -0.045785 & -0.169506 & 0.758813 & 0.062276 & -0.118420 \\
\hline MARK 9 & -0.082887 & -0.136596 & -0.176939 & 0.784284 & -0.033467 & -0.144715 \\
\hline MARK 10 & -0.151457 & -0.123590 & -0.153709 & 0.725358 & -0.095895 & 0.050241 \\
\hline PER 1 & 0.486325 & 0.378028 & 0.344620 & -0.024334 & 0.932932 & 0.259385 \\
\hline PER 2 & 0.342009 & 0.287310 & 0.352620 & -0.068582 & 0.898318 & 0.259746 \\
\hline PER 3 & 0.415235 & 0.259890 & 0.437623 & -0.029938 & 0.890702 & 0.229164 \\
\hline PER 4 & 0.406063 & 0.380414 & 0.453082 & -0.012767 & 0.911195 & 0.259302 \\
\hline PER 5 & 0.468594 & 0.317139 & 0.220652 & 0.014365 & 0.813563 & 0.287031 \\
\hline RES 1 & 0.138157 & 0.369525 & 0.225557 & 0.278031 & 0.105936 & 0.680420 \\
\hline RES 2 & 0.300394 & 0.543312 & 0.368959 & 0.013360 & 0.185475 & 0.889656 \\
\hline RES 3 & 0.404496 & 0.620019 & 0.543134 & -0.142781 & 0.375439 & 0.875125 \\
\hline RES 4 & 0.371461 & 0.494685 & 0.446623 & -0.144877 & 0.231972 & 0.890697 \\
\hline RES 5 & 0.375866 & 0.487709 & 0.502106 & -0.028835 & 0.283636 & 0.877675 \\
\hline
\end{tabular}

TABLE XII. THE RESULT OF THE RESEARCH HYPOTHESIS BASED ON THE RESULTS OF STRUCTURAL MODELS

\begin{tabular}{|c|c|c|c|}
\hline Variables & Path Coefficient & T-statistic & Hypothesis result \\
\hline Management commitment $\rightarrow$ Export entrepreneurship & $0.281 * * *$ & 3.502 & Confirmed \\
\hline Market distance $\rightarrow$ Export entrepreneurship & -0.029 & 0.306 & Confirmed \\
\hline Resources $\rightarrow$ Export entrepreneurship & $0.323 * *$ & 2.909 & Confirmed \\
\hline Intensity of competition $\rightarrow$ Export entrepreneurship & $0.359 * * *$ & 3.618 & Confirmed \\
\hline Export entrepreneurship $\rightarrow$ Export performance & $0.372 * * *$ & 4.059 & Confirmed \\
\hline
\end{tabular}

Management commitment is reflected in activities such as separate units of export, export control and planning, export market research, and regular inspections of the export market. Management commitment to export points out to willingness of export decision makers in the company to allocate appropriate financial, human, and managerial resources. The tendency reduces export risk and obstacles that a company may be encountered in its activities. Moreover, it attracts stronger support from foreign distributors. Hence, results of testing hypothesis are consistent with the literature and confirm them. The second research hypothesis evaluates the impact of company resources on export entrepreneurship. Resources have been evaluated with dimensions of experience and structure. Results and outputs of the software in this study show that resource has a significant positive impact on export entrepreneurship with a path coefficient of 0.323 and t-statistic of 2.909. Therefore, one can assert in interpreting the test results that increasing experience and structural resources of the company will increase, improve, and develop export entrepreneurship significantly. In terms of experience resources (experience in the organization), company must pay attention to the differences between basic experiences and international experiences. Basic experiences refer to the relationships of knowledge in business activities in a competitive industry; it provides the foundation of internationalization process. On the contrary, international experience refers to knowledge about foreign markets. This type of experience will lead to the creation of specialized knowledge regarding export activities and it provides necessary information to adapt to foreign markets. Having international experience reduces risk of exports and barriers to entry into international markets; besides, resource is one of the effective and important variables in export entrepreneurship. Consequently, results of testing hypothesis are consistent with the literature and confirm them. 
The third research hypothesis evaluates the impact of company competition intensity on export entrepreneurship. Results and outputs of the software in this study show that competition intensity has a significant positive impact on export entrepreneurship with a path coefficient of 0.359 and t-statistic of 3.618. In this regard, it can be asserted that increasing competition intensity will increase, improve, and develop export entrepreneurship significantly. Intensity of industry competition shows the rivalry relationships among small, medium, and large firms. At first glance, it can be argued about industries with less competition intensity that companies try to employ the approaches leading to full control to exploit all benefits of investment. Therefore, when competition increases, the companies prefer to contribute partners because it reduces their bargaining power is reduced. On the contrary, Experimental findings have not confirmed this hypothesis. When competition increases in reality, companies prefer not to enter fully cooperative strategies because contribution reduces their assertiveness to respond quickly to competitors. With regard to contents extracted from the literature, the results of this hypothesis are in line with the available literature and confirm them. The fourth research hypothesis evaluates the negative impact of market distance on export entrepreneurship. Results and outputs of the software in this study show that market distance has a negative impact on export entrepreneurship with a path coefficient of -0.029 and t-statistic of 0.306 .

Accordingly, it can be stated that increasing market distance has an adverse effect on the development of export entrepreneurship. Companies export their products to foreign markets to enjoy competitive advantages of a certain geographic region, to earn benefits of increase in market size, and to achieve a better position comparing to domestic and foreign rivals. Market distance means the economic, legal, social, and cultural difference between the local market and foreign markets. Market distance is one of the most remarkable barriers in the internationalization process of companies; it influences severely on the time and the way to enter foreign markets. Thus, the more is the distance between domestic market and foreign markets, the less will be market and foreign markets; thus the activities to develop export entrepreneurship will be decreased and faded. Therefore, the results of this hypothesis are in line with the available literature and confirm them. The fifth research hypothesis evaluates the positive impact of export entrepreneurship on export performance. Export performance in this study has been evaluated by rate, speed, and scale. Results and outputs of the software in this study show that export entrepreneurship (as a construct) has a positive impact on export performance with a path coefficient of 0.0372 and t-statistic of 4.059. Export entrepreneurship is a process in which individuals will benefit from market opportunities in foreign markets by themselves or within the organization by considering available resources and environmental factors that effect on them. In fact, institutional entrepreneurs are individuals who are actively in search of export opportunities while keeping in mind establishment of innovation in product or market. Export entrepreneurship is categorized in the group of programs and activities that are conducted to improve export performance. According to studies and literature, this variable has good impact on improving export performance. Hence, the results of this hypothesis are in line with the available literature and confirm them. The result of testing first research hypothesis is consistent with the findings in $[10,11]$. The second research hypothesis is in line with a part of results shown in $[12,13]$. Third research hypothesis results are in agreement with [14, 15]. Fourth research hypothesis confirms the results [16, 17]. Fifth research hypothesis is in accordance with [18, 19].

\section{SUGGESTIONS FOR FURTHER STUDIES}

It is suggested that a research is conducted for a longer period, for example some years, to study the impact of export entrepreneurship on export performance better; in this way, the results will be more sustainable. Future studies can study the impact of other variables such as export problems, export incentives, export experience, etc. on export performance.

\section{REFERENCES}

[1] M. Haqiqi, M. Firuzian, S. Najafi Majd, "Identification of the Determining Factors of the Export Performance in the Food Industries", Iranian Journal of Business Management, Vol. 1, No. 4, pp. 12-43, 2008

[2] N. A. Dehghan, "Study, classification and selection of strategies for entering international markets", Second International Conference on Strategic Management, Iran: Tehran, Vol. 2, No. 3, pp. 10-12, 2007

[3] A. Rosta, V. Davar, E. Abdolhamid, Marketing Management, Tehran: SAMT Publication, 2004

[4] H. Rezvani, F. Gol Alizadeh, "Evaluation and Analysis of the Strategies of Food Products Entry to Foreign Markets", Strategic Management Journal, Vol. 1, No. 2, pp. 71-100, 2011

[5] K. I. Ibeh, S. Young, "Exporting as an entrepreneurial act-An empirical study of Nigerian firms", European Journal of Marketing, Vol. 35, No. 2, pp. 566-586, 2001

[6] J. Barney, "Firm resources and sustained competitive advantage", Journal of Management, Vol. 17, No. 3, pp. 99-120, 1991

[7] R. Helm, S. Gritsch, "Examining the influence of uncertainty on marketing mix strategy elements in emerging business to business export-markets", International Business Review, Vol. 23, No. 2, pp. 418428,2014

[8] A. Ghasemi, Designing effective model of export incentives to improve export performance through dynamic capabilities of the organization, Case study of small and medium industries in industrial region of Khorasan Razavi, 2013

[9] J. Henseler, C. M. Ringle, R. R. Sinkovics, "The use of partial least squares path modeling in international marketing", Advances in International Marketing, Vol. 20, No. 3, pp. 277-319, 2009

[10] A. Navarro, F. J. Rondan, F. J. Acedo, "The importance of an exportoriented culture for export performance", European Journal of International Management, Vol. 7, No. 5, pp. 254-277, 2013

[11] C. Styles, T. Ambler, "The impact of relational variables on export performance: An empirical investigation in Australia and the UK", Australian Journal of Management, Vol. 25, No. 2, pp. $261-281,2000$

[12] E. Ruzo, F. Losada, A. Navarro, J. A. Díez, "Resources and international marketing strategy in export firms: Implications for export performance", Management Research Review, Vol. 34, No. 2, pp. 496518,2011

[13] F. Vermeulen, H. Barkema, "Pace, rhythm, and scope: Process dependence in building a profitable multinational corporation", Strategic Management Journal, Vol. 23, No. 5, pp. 637-653, 2002

[14] A. Navarro, J. Arenas, F. J. Rondan, "External environment and the moderating role of export market orientation", Journal of Business Research, Vol. 67, No. 2, pp. 740-745, 2014 
[15] J. D. Mittelstaedt, W. A. Ward, E. Nowlin, "Location, industrial concentration and the propensity of small US firms to export: Entrepreneurship in the international marketplace", International Marketing Review, Vol. 23, No. 2, pp. 486-503, 2006

[16] N. Prime, C. Obadia, I. Vida, "Psychic distance in exporter - importer relations hips: A grounded theory a pproach", International Business Review, Vol. 18, No. 3, pp. $184-198,2009$

[17] C. M. Sousa, F. Bradley, "Effects of export assistance and distributor support on the performance of SMEs the case of Portuguese export ventures", International Small Business Journal, Vol. 27, No. 2, pp. 681 $-701,2009$

[18] E. Nemkova, A. L. Souchon, P. Hughes, "Export decision-making orientation: An exploratory study", International Marketing Review, Vol. 29, No. 5, pp. $349-378,2012$

[19] K. S. Powell, "Profitability and speed of foreign market entry", Management International Review, Vol. 54, No. 3, pp. 1-15, 2014 